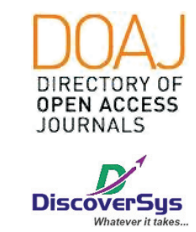

Published by DiscoverSys

\section{Perbedaan kadar serum feritin dengan dan tanpa infeksi Soil - Transmitted Helminth (STH) pada anak sekolah dasar di Pesantren Hidayatullah Tanjung Morawa, Kabupaten Deli Serdang, Sumatera Utara, tahun 2018}

\author{
Noffrizal, ${ }^{1 *}$ Ricke Loesnihari,, ${ }^{2}$ Muzahar $^{2}$
}

\title{
ABSTRACT
}

Background: Worm infections caused by Soil-Transmitted Helminths (STH) currently remains a public health problem in the world, especially Indonesia. STH infection is a risk factor for iron deficiency and eventually reaches the stage of iron deficiency anaemia in chronic infections. Serum ferritin levels were measured as early detection of loss of iron reserves in the body to prevent anaemia. This study aims to compare serum ferritin levels in elementary school/ibtidaiyah children with and without STH infection.

Method: A cross-sectional study was conducted among 60 children at Pesantren Hidayatullah Tanjung Morawa in 2018. About 30 children infected with STH and 30 children not-infected with STH, who fulfilled the inclusion and exclusion criteria were included in this study. Every child was examined for faeces with the Kato-Katz Method and serum ferritin levels with Cobas e411 (Electrochemiluminescence immunoassay). The results obtained were analyzed by Mann Whitney's test by SPSS version 17 for Windows.

Result: Serum ferritin levels in the group with STH infection were $10-281 \mathrm{ng} / \mathrm{ml}$, whereas, in the group that did not suffer from STH infection, the values were $15-283 \mathrm{ng} / \mathrm{ml}$. The median rank between groups was $5.26(>5)$, so clinically, there were significant differences between the two groups. But statistically, there was no significant difference between serum ferritin levels between the two groups $(p=$ 0.24 ), with the significance value of the Mann-Whitney test $p<0.05$. Conclusion: The study showed no significant difference between serum ferritin levels between groups of children who had STH infection and groups of children who did not have STH infection.

Keywords: Soil Transmitted Helminth, Serum ferritin, Elementary School

Cite This Article: Noffrizal, Loesnihari, R., Muzahar. 2020. Perbedaan kadar serum feritin dengan dan tanpa infeksi Soil - Transmitted Helminth (STH) pada anak sekolah dasar di Pesantren Hidayatullah Tanjung Morawa, Kabupaten Deli Serdang, Sumatera Utara, tahun 2018. Intisari Sains Medis 11(1): 310-314. D0l: 10.15562/ism.v11i1.570

\section{ABSTRAK}

Pendahuluan: Infeksi cacing yang disebabkan Soil Transmitted Helminths (STH) saat ini tetap menjadi permasalahan kesehatan masyarakat di dunia khususnya Indonesia. Infeksi STH merupakan salah satu faktor resiko terjadinya defisiensi besi dan akhirnya mencapai tahapan anemia defisiensi besi pada infeksi kronis. Kadar serum feritin diukur sebagai deteksi dini hilangnya cadangan zat besi dalam tubuh untuk mencegah terjadinya anemia. Tujuan penelitian ini adalah untuk untuk membandingkan kadar serum ferritin pada anak sekolah dasar/ ibtidaiyah dengan dan tanpa infeksi STH.

Metode: Sebuah penelitian potong lintang dilakukan terhadap 60 anak pada Pesantren Hidayatullah Tanjung Morawa pada tahun 2018. Sekitar 30 anak terinfeksi STH dan 30 anak tidak terinfeksi STH dimana telah memenuhi kriteria inklusi dan ekslusi terlibat dalam penelitian ini. Setiap anak dilakukan pemeriksaan tinja dengan Metode Kato-Katzserta kadar serum ferritin dengan alat Cobas e411 (Electrochemiluminescence immunoassay). Hasil yang didapat dianalisa dengan uji Mann-Whitney menggunakan SPSS versi 17 untuk Windows.

Hasil: Kadar serum feritin pada kelompok dengan infeksi STH adalah $10-281 \mathrm{ng} / \mathrm{ml}$ sedangkan pada kelompok yang tidak menderita infeksi STH di peroleh nilai $15-283 \mathrm{ng} / \mathrm{ml}$. Rank median antar kelompok 5,26 (>5), maka secara klinis terdapat perbedaan bermakna antara kedua kelompok. Tetapi secara statistik tidak terdapat perbedaan yang bermakna antara kadar serum feritin antara kedua kelompok $(p=0,24)$.

Kesimpulan: Penelitian menunjukkan tidak terdapat perbedaan yang bermakna antara kadar serum feritin antara kelompok anak yang mengalami infeksi STH dan kelompok anak yang tidak mengalami infeksi STH. 


\section{PENDAHULUAN}

Infeksi cacing yang disebabkan Soil Transmitted Helminths (STH) saat ini tetap menjadi permasalahan kesehatan masyarakat di dunia khususnya Indonesia. Infeksi STH tergolong neglected disease yaitu penyakit infeksi yang kurang mendapatkan perhatian. ${ }^{1}$ Diperkirakan penduduk dunia yang menderita infeksi Soil-Transmitted Helminth (STH) pada tahun 2010 adalah 438,9 juta orang terinfeksi jenis hookworm, 819 juta terinfeksi jenis Ascaris lumricoides, 464,6 juta terinfeksi jenis Trichuris trichiura. ${ }^{1}$ Prevalensi tertinggi terjadi nya infeksi Soil-transmitted helminth (STH) dan penyebab penurunan kualitas hidup yang disebabkan kecacingan terjadi di negara Asia dan Afrika. ${ }^{1}$

Beberapa penelitian melaporkan bahwa prevalensi cacing tambang di Amerika latin sebesar $8-10 \%$, ascariasis sebesar $16-18 \%$, dan trichuriasis sebesar 16-19\%. Efek yang sangat mempengaruhi infeksi cacing tambang pada anak ini adalah anemia kekurangan zat besi, Didunia penyebab utama Iron Deficiency Anemia (IDA) adalah infeksi parasit yang disebabkan oleh cacing tambang, cacing cambuk dan cacing gelang dimana perdarahan usus yang disebabkan cacing ini dapat menyebabkan perdarahan di tinja. ${ }^{2}$

Prevalensi STH di Indonesia masih tinggi yaitu $60 \%-80 \%$, dimana prevalensi tertinggi terdapat pada anak SD. Hasil Survei kecacingan oleh Ditjen Pengendalian Penyakit dan Penyehatan Lingkungan (P2PL) tahun 2012 menyebutkan 31,8\% siswa-siswi SD kecacingan Penelitian terakhir di Sumatera Utara kota Medan, tepatnya di Kecamatan Medan Amplas menunjukkan prevalensi STH yang cukup tinggi yaitu $40.3 \%{ }^{3}$

Penelitian lain di Malaysia Barat menemukan hemoglobin, serum feritin, dan kadar zat besi serum menurun pada infeksi STH. ${ }^{4}$ Senada dengan penelitian di Nigeria ditemukan kadar serum ferritin secara signifikan lebih rendah pada kelompok anak yang terinfeksi STH dibandingkan kelompok kontrol. ${ }^{5}$ Berkaitan dengan pemaparan di atas, maka penelitian ini bertujuan untuk membandingkan kadar serum ferritin pada anak sekolah dasar/ibtidaiyah dengan dan tanpa infeksi STH di Pesantren Hidayatullah Tanjung Morawa, Kabupaten Deli Serdang, Sumatera Utara, tahun 2018.

\section{METODE PENELITIAN}

Penelitian dilakukan di Sekolah dasar/ Ibtidaiyah Pesantren Hidayatullah bekerja sama dengan Departemen Patologi Klinik Fakultas Kedokteran Universitas Sumatera Utara/RSUP Haji Adam Malik Medan. Desain penelitian secara potong lintang (cross-sectional) yang dilakukan pada bulan Februari 2018 sampai dengan bulan Agustus 2018.

Populasi penelitian adalah Anak SD/ Ibtidaiyah yang mengalami infeksi Soil-Transmitted Helminth (STH) di Tanjung Morawa, Sumatera Utara. Subjek penelitian adalah 60 anak (30 anak yang terinfeksi STH dan 30 anak yang tidak terinfeksi STH) yang telah melalui proses inklusi yaitu anak SD kelas I-VI, dari hasil pemeriksaan Kato-katz didapati salah satu atau kombinasi dari telur Ascaris lumbricoides, Trichuris trichiura, ataupun hookworm, anak dengan status gizi baik, anak yang tinggal didaerah yang sama dan eksklusi yaitu mengkonsumsi antihelmintik $<1$ bulan sebelum penelitian, mengkonsumsi zat besi dalam waktu 3 bulan terakhir sebelum penelitian, mengkonsumsi Antibiotik cth: Tetrasiklin, menggunakan obat pencahar. Setiap anak dilakukan Pemeriksaan tinja dengan Metode Kato-Katz dan pemeriksaan kadar serum ferritin menggunakan alat Cobas e411 dengan prinsip pemeriksaan ECLIA (Electrochemiluminescence immunoassay).

Penelitian ini dilakukan setelah mendapat persetujuan dari Komite Penelitian Bidang Kesehatan Fakultas Kedokteran Universitas Sumatera Medan. Hasil penelitian dianalisa secara statistik dengan menggunakan komputerisasi. Gambaran karakteristik pada subjek penelitian disajikan dalam bentuk tabulasi dan dideskripsikan. Perbedaan kadar serum feritin antara kelompok anak yang mengalami infeksi STH dan kelompok anak yang tidak mengalami infeksi STH dianalisis dengan menggunakan uji Mann Whitney dengan nilai signifikansi $\mathrm{p}<0,05$ menggunakan piranti lunak SPSS versi 17 untuk Windows.

\section{HASIL}

Penelitian ini dilakukan pada populasi anak sekolah Ibtidaiyyah Pesantren Hidayatullah yang seluruhnya berjumlah 368 anak dan yang bersedia menjadi subjek penelitian sebanyak 298 anak yang diperiksa fesesnya dan ditemukan diantaranya terdapat 30 anak $(10,1 \%)$ yang terinfeksi STH (Gambar 1). Adapun jumlah responden penelitian yang memenuhi kriteria inklusi dan eksklusi setelah dilakukan pemeriksaan feses untuk pemeriksaan serum ferritin adalah sebanyak 60 orang (Tabel 1).

Berdasarkan Tabel 1, mayoritas berjenis kelamin laki-laki pada kelompok yang terinfeksi STH (56,7\%) maupun yang tidak terinfeksi STH $(70,0 \%)$. Sebagian besar pekerjaan orang tua reseponden penelitian adalah sebagai buruh pada kelompok anak yang terinfeksi STH (66,7\%) maupun pada kelompok tidak terinfeksi STH (46,6\%). Sedangkan menurut pendidikan orang tua mayoritas orang tua 
Tabel 1 Karakteristik demografi subjek penelitian

\begin{tabular}{|c|c|c|c|c|}
\hline \multirow[b]{2}{*}{ Karakteristik } & \multicolumn{4}{|c|}{ Jumlah Subjek ( $N=60)$} \\
\hline & Positif $n=30$ & $\%$ & Negatif $n=30$ & $\%$ \\
\hline \multicolumn{5}{|l|}{ Jenis Kelamin } \\
\hline Laki-laki & 17 & 56,7 & 21 & 70,0 \\
\hline Perempuan & 13 & 43,3 & 9 & 30,0 \\
\hline \multicolumn{5}{|c|}{ Pekerjaan Orang tua } \\
\hline PNS & 3 & 10 & 6 & 20,0 \\
\hline Wiraswasta & 5 & 16,7 & 7 & 23,3 \\
\hline Buruh & 20 & 66,7 & 14 & 46,6 \\
\hline Petani & 2 & 6,7 & 3 & 10,0 \\
\hline \multicolumn{5}{|c|}{ Pendidikan Orang tua } \\
\hline PT & 5 & 16,7 & 8 & 26,7 \\
\hline SLTA & 11 & 36,7 & 12 & 40,0 \\
\hline SLTP & 10 & 33,3 & 7 & 23,3 \\
\hline SD & 4 & 13,3 & 3 & 10,0 \\
\hline
\end{tabular}

Tabel 2 Karakteristik berdasarkan antropometri subjek penelitian

\begin{tabular}{|c|c|c|c|c|}
\hline \multirow[b]{3}{*}{ Parameter } & \multicolumn{4}{|c|}{ Jumlah Subjek STH $(\mathrm{N}=60)$} \\
\hline & \multicolumn{2}{|c|}{ Positif $(\mathrm{N}=\mathbf{3 0})$} & \multicolumn{2}{|c|}{ Negatif $(\mathrm{N}=30)$} \\
\hline & Rerata & (SB) & Rerata & (SB) \\
\hline Umur (tahun) & 9,4 & 1,94 & 9,2 & 2,17 \\
\hline Berat badan (kg) & 29,0 & 5,71 & 30,1 & 7,42 \\
\hline Tinggi badan $(\mathrm{cm})$ & 128,1 & 7,04 & 130,96 & 7,75 \\
\hline Status Gizi baik (n,\%) & $30(100 \%)$ & - & $30(100 \%)$ & - \\
\hline
\end{tabular}

Tabel 3 Perbedaan kadar serum feritin antara kelompok STH dan Non-STH

\begin{tabular}{lcc}
\hline Hasil Pemeriksaan & Median (Minimum-Maksimum) & p \\
\hline Feritin STH $(\mathrm{n}=30)$ & $50,5(10-281)$ & $0,24^{*}$ \\
Feritin non-STH $(\mathrm{n}=30)$ & $72,0(15-283)$ & \\
\hline
\end{tabular}

${ }^{*}$ Uji Mann-Whitney: dikatakan bermakna apabila nilai p kurang dari 0,05; Rerata rangking STH $=27,87$ dan non STH $=33,13$

anak pada kelompok yang terinfeksi STH adalah berpendidikan SLTA $(36,7 \%)$ maupun pada kelompok tidak terinfeksi STH $(40,0 \%)$ (Tabel 1$)$.

Berdasarkan Tabel 2 dapat dilihat bahwa rata-rata umur subjek penelitian pada kelompok terinfeksi STH adalah 9,4 $\pm 1,94$ tahun dan 9,2 $\pm 2,17$ tahun pada kelompok tidak terinfeksi STH. Rerata berat badan subjek penelitian pada kelompok STH adalah $29,0 \pm 5,71 \mathrm{~kg}$ dan $29,0 \pm 5,71 \mathrm{~kg}$ pada kelompok tanpa infeksi STH (Tabel 2). Sedangkan pada kelompok anak terinfeksi STH ini memiliki rata-rata tinggi badan $128,1 \pm 7,04 \mathrm{~cm}$ dan $130,96 \pm 7,75 \mathrm{~cm}$ pada kelompok tanpa infeksi STH. Keseluruhan status gizi responden penelitian pada kedua kelompok adalah baik (100,0\%) (Tabel 2).

Berdasarkan Tabel 3 di bawah dapat dilihat bahwasannya nilai median kadar feritin pada kelompok anak terinfeksi STH adalah $50 \mathrm{ng} / \mathrm{dl}$ dengan rentangan nilai minimum-maksimum adalah 10 ng/dl - $281 \mathrm{ng} / \mathrm{dl}$. Berbeda dengan kelompok anak yang tidak terinfeksi STH memiliki median kadar feritin $72 \mathrm{ng} / \mathrm{dl}$ dengan nilai minimum-maksimum adalah $15 \mathrm{ng} / \mathrm{dl}-283 \mathrm{ng} / \mathrm{dl}$ (Tabel 3). Dari Tabel 3 juga dapat terlihat bahwa tidak terdapat perbedaan bermakna kadar serum feritin antara kelompok anak yang mengalami infeksi STH dan kelompok anak yang tidak mengalami infeksi STH $(\mathrm{p}=0,24)$.

\section{PEMBAHASAN}

Pada penelitian ini ditemukan prevalensi infeksi STH di lokasi penelitian sebesar 10,1\%. Berdasarkan klasifikasi prevalensi penyakit cacingan WHO, 


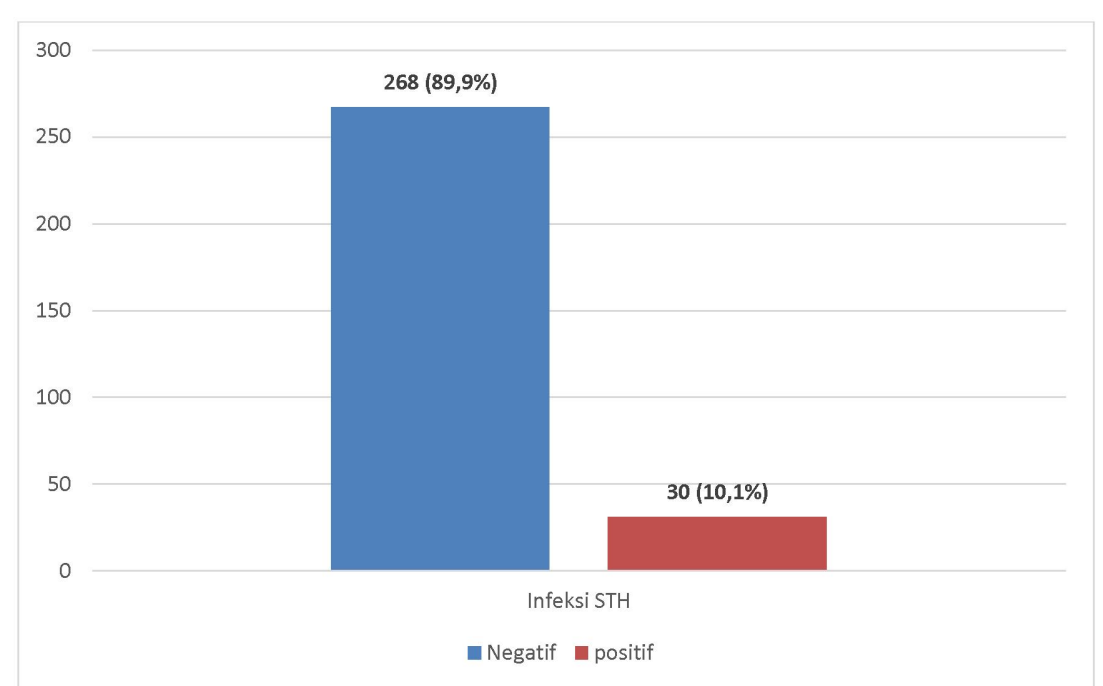

Gambar 1 Angka insidensi infeksi STH di Sekolah Ibtidaiyyah Pesantren Hidayatullah Tanjung Morawa Sumatera Utara setelah pemeriksaan feses

prevalensi di lokasi penelitian ini terkategori prevalensi rendah yaitu dibawah $20 \%{ }^{6}$ Tingginya prevalensi kecacingan pada anak ditunjang oleh perilaku anak-anak usia sekolah dasar yang sering bermain dan kontak dengan tanah. ${ }^{7}$ Hal tersebut juga yang dijumpai peneliti pada lokasi penelitian, masih banyak anak-anak sekolah dasar ini bermain di tanah dan sebagian besar tanpa menggunakan alas kaki.

Karakteristik demografi yang didapatkan pada penelitian ini adalah tercatat bahwa pada kelompok anak yang terinfeksi STH adalah berjenis kelamin laki-laki yaitu sebanyak 56,7\%. Hal ini juga sejalan dengan penelitian di sekolah dasar kota Medan dimana mayoritas anak sekolah dasar yang terinfeksi STH adalah anak yang berjenis kelamin laki-laki yaitu 55,6\%. ${ }^{3}$ Kebiasaan bermain anak laki-laki diamati peneliti lebih cendrung bermain di area halaman tanah dengan berlari-lari dan bermain bahkan tanpa menggunakan alas kaki. kecendrungan anak laki-laki dengan kebiasaan ini juga dikarenakan kurang pedulinya mereka terhadap kebersihan diri (personal hygiene). Untuk tingkat pendidikan orang tua anak kelompok STH dominan memiliki pendidikan SLTA (36,7\%) Berdasarkan pekerjaan orang tua dominan anak pada kelompok STH memiliki pekerjaan buruh sebesar $66,7 \%$. Karakteristik antropometri subjek penelitian seluruhnya mempresentasikan status nilai gizi yang baik pada kelompok STH dan non STH berdasarkan kurva CDC 2000 seperti yang tercantum pada Tabel 2 di atas.

Kadar serum feritin lebih rendah pada kelompok anak dengan STH dibandingkan kelompok anak non STH. Nilai minimal dan maksimal kadar serum feritin pada kelompok anak dengan infeksi STH adalah $10-281 \mathrm{ng} / \mathrm{ml}$ sedangkan pada kelompok anak yang tidak menderita infeksi STH di peroleh nilai minimal dan maksimal kadar serum feritin adalah $15-283$ ng/ml. Karena selisih median (rank median) antar kelompok 5,26 (>5) maka secara klinis terdapat perbedaan bermakna antara kadar feritin kelompok dengan infeksi STH dengan kadar feritin kelompok tidak dengan STH (Tabel 3). Pada infeksi STH terutama disebabkan oleh dampak infeksi yang bersifat kronis dan membahayakan kesehatan meskipun infeksi STH tidak menimbulkan dampak kematian. Infeksi STH yang berat dapat mengganggu perkembangan fisik dan perkembangan kognitif dan menjadi penyebab kekurangan gizi / mikronutrien seperti anemia defisiensi besi yang menyebabkan kegiatan sekolah yang buruk dan ketidak hadiran dan menurunkan intelegensi anak sekolah. ${ }^{8-10}$ Kadar serum feritin merupakan indikator spesifik yang sering digunakan untuk menilai status penyimpanan besi dalam tubuh. ${ }^{11}$ Pada Infeksi STH dapat dijumpai penurunan kadar serum ferritin. ${ }^{5}$

Pada penelitian ini secara statistik tidak terdapat perbedaan kadar serum feritin yang bermakna antara kelompok anak yang mengalami infeksi STH dan kelompok anak yang tidak mengalami infeksi STH. Walaupun tidak terdapat perbedaan yang bermakna, namun nilai rerata kadar serum feritin pada anak yang terinfeksi STH lebih rendah dibandingkan anak yang tidak terinfeksi STH. Hal yang sama juga pernah dilaporkan dalam penelitian systematic review dan meta analisis pada tahun 2014 oleh de Gier dkk, mendapatkan tidak ada perbedaan bermakna antara kadar serum feritin pada anak dengan dan tanpa infeksi STH, akan tetapi terjadi peningkatan kadar serum feritin pada anak yang terinfeksi STH setelah menkonsumsi obat antihelmintik. ${ }^{12}$ Namun hasil yang berbeda diperoleh pada penelitian di Manado tahun 2013 yang memperoleh perbedaan yang bermakna dari kadar serum feritin pada anak yang menderita infeksi STH dengan nilai $\mathrm{p}=0,001 .{ }^{13}$

Zat besi diperlukan oleh sistem imun atau sel makrofag untuk menghasilkan Highly Toxic Hidroksikal yang berfungsi melawan patogen mikroorganisme juga membutuhkan zat besi untuk berkembang biak dalam tubuh. Dalam kondisi ketidakseimbangan besi, maka ditingkat seluler akan melakukan kompensansi dengan membongkar zat besi yang sebelumnya tidak terpakai atau sebagai cadangan zat besi dalam tubuh (ferritin). ${ }^{14}$ Penurunan kadar serum ferritin pada infeksi STH dikaitkan dengan efek yang ditimbulkan infeksi STH, berupa gangguan penyerapan besi, perdarahan saluran cerna dan menurunnya nafsu makan. ${ }^{15}$ Nilai serum ferritin yang rendah mencerminkan suatu kondisi awal terjadinya defisiensi besi. ${ }^{11}$ 


\section{SIMPULAN}

Hasil penelitian ini secara garis besar menyimpulkan bahwa tidak terdapat perbedaan yang bermakna antara kadar serum feritin antara kelompok anak yang mengalami infeksi STH dan kelompok anak yang tidak mengalami infeksi STH pada anak sekolah dasar di Pesantren Hidayatullah Tanjung Morawa, Kabupaten Deli Serdang, Sumatera Utara, tahun 2018. Akan tetapi, penelitian lebih lanjut yang dilakukan secara multi-senter dengan desain penelitian longitudinal dapat dilakukan untuk menggeneralisasikan hasil pada masyarakat yang lebih luas dan mencari hubungan sebab akibat.

\section{KONFLIK KEPENTINGAN}

Tidak terdapat konflik kepentingan dalam penulisan laporan penelitian ini.

\section{ETIKA PENELITIAN}

Persetujuan etik telah diperoleh pada penelitian ini sebelum penelitian berjalan oleh Komisi Etik Fakultas Kedokteran, Universitas Sumatera Utara, Medan, Indonesia.

\section{PENDANAAN}

Penulis bertanggung jawab terhadap pendanaan penelitian ini tanpa melibatkan sponsor, beasiswa, atau sumber pendanaan lainnya.

\section{KONTRIBUSI PENULIS}

Seluruh penulis bertanggung jawab dalam penulisan laporan penelitian ini baik dari tahap penyusunan kerangka konsep hingga interpretasi hasil penelitian dalam bentuk publikasi.

\section{DAFTAR PUSTAKA}

1. Zerdo Z, Yohanes T, Tariku B. Soil-Transmitted Helminth Reinfection and Associated Risk Factors among SchoolAge Children in Chencha District, Southern Ethiopia: A Cross-Sectional Study. J Parasitol Res. 2016;2016:4737891.

2. Mohammed Mujib AS, Mohammad Mahmud AS, Halder M, Monirul Hasan CM. Study of Hematological Parameters in Children Suffering from Iron Deficiency Anaemia in Chattagram Maa-o-Shishu General Hospital, Chittagong, Bangladesh. Anemia. 2014;2014:503981.
3. Darlan DM, Kaban FFV. Hubungan antara Infeksi Soil Transmitted Helminth Infection dan Insiden Anemia pada Sekolah Dasar 060925. Jurnal Internasional Pharm Tech Research. 2016;9(6):185-190.

4. Ngui R, Lim YA, Chong Kin L, Sek Chuen C, Jaffar S. Association between anaemia, iron deficiency anaemia, neglected parasitic infections and socioeconomic factors in rural children of West Malaysia. PLoS Negl Trop Dis. 2012;6(3):e1550.

5. Adebara OV, Ernest SK, Ojuano IA. Association between intestinal helminthiasis and serum feritin levels among school children. Open Journal of Pediatrics. 2011;1(2):12-16.

6. Brooker S, Clements AC, Bundy DA. Global epidemiology, ecology and control of soil-transmitted helminth infections. Adv Parasitol. 2006;62:221-261.

7. Blouin B, Casapía M, Joseph L, Kaufman JS, Larson C, Gyorkos TW. The effect of cumulative soil-transmitted helminth infections over time on child development: a 4-year longitudinal cohort study in preschool children using Bayesian methods to adjust for exposure misclassification. Int J Epidemiol. 2018;47(4):1180-1194.

8. Weatherhead JE, Hotez PJ, Mejia R. The Global State of Helminth Control and Elimination in Children. Pediatr Clin North Am. 2017;64(4):867-877.

9. Bethony J, Brooker S, Albonico M, et al. Soil-transmitted helminth infections: ascariasis, trichuriasis, and hookworm. Lancet. 2006;367(9521):1521-1532.

10. Hotez PJ, Brindley PJ, Bethony JM, King CH, Pearce EJ, Jacobson J. Helminth infections: the great neglected tropical diseases. J Clin Invest. 2008;118(4):1311-1321.

11. Wu AC, Lesperance L, Bernstein H. Screening for iron deficiency. Pediatr Rev. 2002;23(5):171-178.

12. de Gier B, Campos Ponce M, van de Bor M, Doak CM, Polman K. Helminth infections and micronutrients in school-age children: a systematic review and meta-analysis. Am J Clin Nutr. 2014;99(6):1499-1509.

13. Buhang SM, Mayulu N, Rottie J. Hubungan kejadian Malaria dan kecacingan dengan kadar feritin pada murid sekolah dasar di kabupaten bolang mongondow utara. eJournal Keperawatan (e-Kp). 2013;1(1):1-8.

14. Jonker FA, Calis JC, Phiri K, Brienen EAT, Khoffi H, Brabin BJ, et al. Real-time PCR demonstrates Ancylostoma duodenale is a key factor in the etiology of severe anemia and iron deficiency in Malawian pre-school children. PLoS Negl Trop Dis. 2012;6(3):e1555.

15. Osazuwa F, Ayo OM, Imade P. A significant association between intestinal helminth infection and anaemia burden in children in rural communities of Edo state, Nigeria. $\mathrm{N}$ Am J Med Sci. 2011;3(1):30-34.

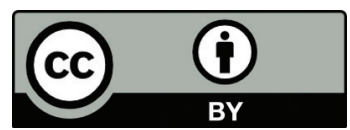

This work is licensed under a Creative Commons Attribution 